\title{
KONSERVASI DAN REVITALISASI BAHASA SEBAGAI SALAH SATU UPAYA INTERNASIONALISASI BAHASA INDONESIA
}

\author{
Yusida Gloriani
}

\section{PENDAHULUAN}

Jika kita menengok kembali pada isi Sumpah Pemuda tahun 1928 yang berkaitan dengan bahasa yaitu: Kami Putra dan Putri Indonesia, menjunjung bahasa persatuan bahasa Indonesia, maka kita bisa mengambil makna dari pernyataan tersebut yaitu bahwa para pemuda Indonesia pada saat diikrarkannya Sumpah Pemuda memiliki sifat dan rasa kebangsaan yang tinggi. Mereka bersumpah dengan tekad yang bulat menyatakan diri untuk menjaga tanah air, bangsa, dan bahasa Indonesia sebagai bahasa persatuan.

Apa makna dari sumpah: menjunjung bahasa persatuan bahasa Indonesia? Kata 'menjunjung' menurut Kamus Bahasa Indonesia adalah membawa di atas kepala, menaati, memuliakan, menghormati, menghargai. Berdasarkan arti tersebut, maka kita selaku bangsa Indonesia, sebagai generasi penerus bangsa, berkewajiban untuk melanjutkan cita-cita tersebut. Namun ternyata untuk melaksanakan amanat tersebut tidak semudah mengucapkannya. Seiring dengan perkembangan zaman, sifat bangga dan loyal pada bahasa sendiri yaitu bahasa Indonesia semakin terkikis. Masuknya budaya asing, pengaruh bahasa pada media sosial, perkembangan teknologi komunikasi ternyata memberikan dampak, khususnya anak muda lebih bangga jika berkomunikasi menggunakan bahasa milik orang lain (bahasa asing) yang dianggapnya lebih modern atau lebih dihormati.

Agar bahasa Indonesia bernilai dan sejajar dengan bahasa-bahasa negara lain yang sudah diakui dunia, maka perlu kiranya pemerintah bersama-sama masyarakat Indonesia membuat strategi untuk pemertahanan dan pengembangan bahasa Indonesia. Salah satu strategi yang sudah direncanakan pemerintah yaitu seperti yang tercantum dalam Undang Undang Nomor 24 Tahun 2009 tentang Bendera, Bahasa, dan Lambang Negara, serta Lagu Kebangsaan, pasal 44 menyebutkan bahwa (1) Pemerintah meningkatkan fungsi Bahasa Indonesia menjadi bahasa internasional secara bertahap, sistematis, dan berkelanjutan; (2) Peningkatan fungsi bahasa Indonesia menjadi bahasa Internasional sebagaimana dimaksud pada ayat (1) dikoordinasi oleh lembaga kebahasaan; (3) Ketentuan lebih lanjut mengenai peningkatan fungsi bahasa Indonesia menjadi bahasa internasional sebagaimana dimaksud pada ayat (1) diatur dalam peraturan pemerintah. Berdasarkan undang-undang tersebut berarti kedudukan bahasa 
Indonesia menuju posisi lebih tinggi dibandingkan posisi sebelumnya, yaitu sebagai bahasa nasional dan bahasa negara, menuju ke bahasa internasional.

Pemerintah, dalam hal ini Pusat Pengembangan dan Pelindungan (Pusbanglin), Badan Pengembangan dan Pembinaan Bahasa (Badan Bahasa), Kementerian Pendidikan dan Kebudayaan memiliki strategi untuk mewujudkan internasionalisasi bahasa Indonesia. Strategi yang akan dilakukan menurut Dr. Sugiyono (Kepala Pusat Pengembangan dan Pelindungan) adalah: "Pertama, meningkatkan jumlah kosakata. Kedua, mengembangkan Uji Kemahiran Berbahasa Indonesia (UKBI). Ketiga, kita akan mencoba membawa Indonesia ke luar negeri, caranya dengan menyusun kamus ASEAN (terdiri dari sepuluh negara anggota ASEAN) dan akan diberi nama kamus Masyarakat Ekonomi ASEAN (MEA), serta kerja sama dengan kedutaan dan perguruan tinggi yang sudah terjalin sejak beberapa tahun lalu. “

Masih menurut Sugiyono, selain ketiga strategi yang mendukung internasionalisasi bahasa Indonesia di atas, Pusbanglin juga memiliki program pelindungan, yaitu konservasi dan revitalisasi bahasa dan sastra Indonesia dan daerah. Selanjutnya, untuk memahami tentang konservasi dan revitalisasi bahasa dalam mendukung internasionalisasi bahasa Indonesia akan dipaparkan di bawah ini.

\section{KONSERVASI DAN REVITALISASI BAHASA INDONESIA}

\section{Konservasi Bahasa Indonesia}

Secara harfiah, konservasi berasal dari bahasa Inggris yaitu conservation yang artinya pelestarian atau perlindungan. Pengertian konservasi menurut Kamus Besar Bahasa Indonesia (KBBI) adalah: (1) pemeliharaan dan perlindungan sesuatu secara teratur untuk mencegah kerusakan dan kemusnahan dengan jalan mengawetkan; pengawetan; pelestarian; (2) proses menyaput bagian dalam badan mobil, kapal, dsb. untuk mencegah karat.

Jika dikaitkan antara konservasi dengan bahasa Indonesia, maka arti konservasi bahasa Indonesia adalah melakukan pemeliharaan dan perlindungan secara teratur terhadap bahasa Indonesia untuk mencegah terjadinya kerusakan atau kemusnahan pada bahasa Indonesia. Benarkah bahasa Indonesia yang kita cintai ini bisa menjadi rusak atau musnah?

Bahasa Indonesia bisa menjadi rusak atau bahkan musnah jika masyarakat Indonesia sebagai pemilik dan pengguna bahasa Indonesia tidak menjaganya, melindunginya, melestarikannya, atau tidak menggunakannya secara baik dan benar. Ketidakkonsistenan sikap bangsa Indonesia terhadap bahasanya sendiri juga patut dipertanyakan. Ketidakkonsistenan ini berkaitan dengan ketidaktaatazasan dalam realisasi norma pemakaian bahasa Indonesia sesuai 
kedudukan dan fungsinya. Bahasa Indonesia seharusnya dipelihara dan dijunjung tinggi tetapi mengapa seperti tampak asing di negeri sendiri.

Hal di atas diperkuat oleh pendapat Sulisyaningsih (2014), bahwa sikap taat azas masyarakat Indonesia terhadap penggunaan kaidah-kaidah kebahasaan sesuai konteks komunikasi masih dipertanyakan. Terpinggirnya bahasa Indonesia diantaranya ditandai oleh memudarnya kebanggaan terhadap bahasa Indonesia yang baku dan benar, terutama di kalangan anak muda. Perasaan rendah diri acap kali juga menjangkit pada kalangan muda/pelajar/mahasiswa ketika menggunakan bahasa Indonesia yang baku dan benar. Kesan yang muncul adalah ketika seseorang menggunakan istilah asing terasa lebih hebat dibandingkan menggunakan bahasanya sendiri. Hal ini menjadi bukti bahwa masih banyak diantara kita yang belum memiliki rasa percaya diri terhadap bahasa Indonesia. Terlebih fenomena penggunaan bahasa Indonesia dalam dunia bisnis.

Seiring arus globalisasi, pelaku pada dunia bisnis lebih menyukai dan menghargai penggunaan bahasa asing (Inggris) dibandingkan dengan bahasa Indonesia. Hal ini diperparah dengan penggunaan bahasa Inggris yang tidak sesuai terutama pada saat mempromosikan produknya, Mereka menggunakan campuran bahasa Inggris "setengah-setengah" dengan bahasa Indonesia. Contoh:

(1) Special Promo, Elite, the comfortable world, diskon 40\%, up grade size.

Dapatkan penawaran menarik ini hanya di toko .... kesayangan Anda.

(2) Solahart, hot water free from the sun. Orang cerdas pilih yang berkualitas.

(3) Pribadi Cellular, jual macam-macam merk handphone, cicilan 0\% 6 s/d 12 bulan, tanpa DP (Surat Kabar Radar Cirebon, 23 Oktober 2017)

Menurut Sulistyaningsih (2014), lunturnya kesetiaan dan kebanggaan pada bahasa Indonesia merupakan sebuah realitas ironis, sebab pada saat yang bersamaan bahasa Indonesia kini menjadi bahan pembelajaran yang menyedot banyak peminat di berbagai negara yaitu di Australia, Belanda, Jepang, USA, Inggris, RRC, dan Korea Selatan.

Era globalisasi ini merupakan tantangan bagi bangsa Indonesia untuk dapat mempertahankan diri di tengah-tengah pergaulan antarbangsa. Bangsa Indonesia harus mempersiapkan diri dengan baik dan penuh perhitungan. Salah satu hal yang harus diperhatikan adalah masalah jati diri bangsa yang diperlihatkan melalui jati diri bahasa. Jati diri bahasa Indonesia adalah tata bahasanya yang sederhana, mudah dipelajari, dan tidak rumit (Muslich dan Oka, 2010 ).

Berkaitan dengan internasionalisasi bahasa Indonesia, pemerintah tidak boleh bergerak setengah hati dalam pengembangan dan pemertahanan bahasa Indonesia. Pemerintah memiliki peranan yang sangat penting dalam merencanakan dan melaksanakan politik bahasa Indonesia. Jika pemerintah kurang merespons terhadap eksistensi bahasa Indonesia, bukan tidak mungkin bahasa Indonesia yang berada pada urutan ke-10 sebagai bahasa yang paling banyak dipakai di dunia, 
akan semakin terpinggirkan. Sementara negara lain mulai mengapresiasi keberadaan bahasa Indonesia. (Sulistyaningsih, 2014).

Secara normatif keberpihakan pemerintah terhadap bahasa Indonesia sudah cukup baik, ditandai dengan disahkannya Undang-Undang Nomor 24 Tahun 2009 tentang Bendera, bahasa, dan Lambang Negara, serta Lagu Kebangsaan. Namun secara implementatif Undang-Undang Nomor 24 Tahun 2009 khususnya tentang bahasa belum dapat dilaksanakan secara efektif. Pemanfaatan bahasa asing yang tidak sesuai dengan bahasa Indonesia dalam acara resmi atau formal, dalam bidang pendidikan, pada forum nasional maupun internasional masih banyak yang tidak sejalan dengan UU Nomor 24 Tahun 2009 ini. Ironisnya, undang-undang ini tidak cukup kuat dalam hal pemberian sanksi, oleh karena itu kesalahan penggunaan bahasa Indonesia seringkali terjadi dan dibiarkan berlalu begitu saja. Hal ini tentu saja akan berdampak buruk bagi kelangsungan bahasa Indonesia, terlebih lagi jika pemerintah menginginkan bahasa Indonesia menjadi bahasa internasional (Sulistyaningsih, 2014).

Sekaitan dengan internasionalisasi bahasa Indonesia, Badan Pembinaan dan Pengembangan Bahasa (Badan Bahasa) menyusun perencanaan program pelindungan bahasa dan sastra yang terdiri atas dua, yaitu: program konservasi bahasa dan revitalisasi bahasa. Program konservasi terbagi menjadi dua yaitu konservasi bahasa dan konservasi sastra. Program konservasi bahasa meliputi: kajian murni kebahasaan; penyusunan sistem fonetik, fonologi, morfologi, dan sintaksis; penyusunan sistem semantik; kajian vitalitas bahasa; pemetaan vitalitas bahasa. Sedangkan Program konservasi sastra meliputi: kajian murni kesastraan; pencatatan \& registrasi; kajian vitalitas sastra; dan pemetaan vitalitas sastra. Badan, perorangan, atau kelompok masyarakat yang terlibat dalam konservasi bahasa yaitu: masyarakat/komunitas, Pemda, akademisi/Dosen, peneliti, guru, dan siswa (Kemendikbud, 2016).

\section{Revitalisasi Bahasa Indonesia}

Kata revitalisasi pada Kamus Besar Bahasa Indonesia (KBBI) berarti 'suatu proses atau cara dan perbuatan untuk menghidupkan atau menggiatkan kembali suatu hal yang sebelumnya terberdaya, sehingga revitalisasi berarti menjadikan sesuatu atau perbuatan untuk menjadi vital,' sedangkan vital sendiri memiliki arti sangat penting atau sangat diperlukan sekali untuk kehidupan, dsb.

Revitalisasi bahasa menurut Hinton (2001) dalam Budiwiyanto (2016) adalah upaya untuk mengembalikan bahasa yang terancam punah pada tingkat penggunaan yang lebih baik dalam masyarakat setelah mengalami penurunan penggunaan. Tugas utama revitalisasi bahasa meliputi; 1) mengajarkan bahasa kepada mereka yang tidak mengetahui bahasa itu; 2) membuat orang yang 
mempelajari bahasa dan orang yang sudah mengetahui bahasa itu menggunakannya dalam situasi yang lebih luas.

Hinton (2001) mengusulkan enam upaya nyata dalam mengembalikan penggunaan bahasa yang hampir punah (revitalisasi bahasa), yaitu:

1) belajar beberapa kata, seperti salam, perkenalan, dan percakapan pendek;

2) mengumpulkan publikasi linguistik, catatan lapangan, dan rekaman suara sebagai bagian dari penciptaan sumber daya berbasis masyarakat dan arsip;

3) mengembangkan sistem tulis dan pembuatan kamus berbasis masyarakat dan tata bahasa pedagogis;

4) membuat rekaman audio atau video dari penutur yang tersisa dengan tujuan mendokumentasikan dan mengarsipkan contoh penggunaan bahasa mereka dengan membuat korpus bahan berbagai jenis;

5) mengikuti kelas bahasa atau kemah bahasa; dan

6) menjalankan sekolah imersi penuh (menggunakan bahasa pengantarnya adalah bahasa yang terancam punah) untuk anak-anak pada masyarakat yang memiliki sumber daya untuk mendukung mereka.

Seperti halnya pada program konservasi (pelindungan bahasa dan sastra), maka revitalisasi pun terbagi menjadi dua yaitu revitalisasi bahasa dan revitalisasi sastra. Program kerja pada revitalisasi bahasa meliputi: penyusunan bahan dan model revitalisasi bahasa berbasis komunitas; revitalisasi bahasa berbasis komunitas; dan penyusunan sistem aksara. Sedangkan program revitalisasi sastra meliputi: revitalisasi sastra berbasis komunitas; penyusunan bahan dan model revitalisasi sastra berbasis komunitas; alih wahana dan modifikasi karya sastra; dan penyaduran karya sastra. Yang terlibat dalam program revitalisasi adalah masyarakat/komunitas, Pemda, akademisi/dosen, peneliti, guru , dan siswa.

Untuk memastikan apakah bahasa Indonesia perlu direvitalisasi atau tidak, maka perlu dilakukan penilaian vitalitas atau daya hidup bahasa. Menurut Unesco (2003) dalam Budiwiyanto (2016), daya hidup bahasa dapat diukur dari beberapa indikator. Unesco menggunakan sembilan faktor untuk menentukannya, yaitu:

1) transmisi bahasa antargenerasi;

2) jumlah penutur absolut;

3) proporsi penutur dengan jumlah penduduk keseluruhan;

4) kecenderungan dalam ranah penggunaan bahasa;

5) daya tanggap terhadap ranah baru dan media;

6) materi untuk pendidikan bahasa dan keberaksaraan;

7) kebijakan bahasa oleh pemerintah dan institusi, termasuk status resmi dan penggunaanya;

8) sikap masyarakat penutur terhadap bahasa mereka;

9) jumlah dan kualitas dokumentasi bahasa. 
Berdasarkan penilaian daya hidup bahasa, Unesco menggolongkannya menjadi enam tingkat keadaan bahasa yaitu:

1) aman, jika bahasa dituturkan oleh semua generasi dan transmisi antargenerasi tidak terputus;

2) rentan, jika bahasa dituturkan oleh anak-anak, tetapi hanya pada ranah tertentu;

3) terancam, jika anak-anak tidak lagi menggunakan bahasanya di rumah sebagai bahasa ibu;

4) sangat terancam, jika bahasa hanya digunakan antargenerasi tua, tetapi tidak kepada anak-anak;

5) hampir punah, jika hanya generasi tua yang dapat menuturkan, tetapi jarang digunakan;

6) punah, jika tidak ada penuturnya.

Berdasarkan penilaian daya hidup tersebut, pada tingkat manakah posisi bahasa Indonesia berada? Apakah bahasa Indonesia perlu untuk direvitalisasi? Kita sebagai pemilik bahasa Indonesia yang kita cintai berharap tingkat daya hidup bahasa Indonesia akan tetap aman, artinya bahasa Indonesia harus terus digunakan baik secara lisan maupun tulis oleh semua generasi dan transmisi antargenerasi tidak boleh terputus.

Untuk memelihara agar bahasa Indonesia ada pada tingkat aman, maka kita bangsa Indonesia sebagai penutur asli bahasa Indonesia tidak hanya selalu menggunakan bahasa Indonesia, namun sikap konsisten dan taat norma pun harus diperhatikan. Pada umumnya penutur bahasa Indonesia baru menunjuk-kan keberpihakan dan dukungan secara permukaan, belum menyentuh pada substansi atau orientasi penguasaan Bahasa Indonesia uang sesungguhnya. Menurut Asrini (2014) hakikat penguasaan BI adalah membentuk penutur BI dengan kualifikasi mampu berbahasa Indonesia untuk mengekspresikan gagasan atau idenya sesuai kaidah, mampu berbahasa Indonesia sesuai kedudukan dan fungsinya, serta mampu menunjukkan sikap yang positif terhadap BI.

Bangsa Indonesia sebagai penutur asli BI ternyata masih banyak yang belum bisa menunjukkan sikap positifnya terhadap BI, hal ini dipengaruhi oleh berbagai faktor, baik internal maupun eksternal, diantaranya:

1) ketidakpahaman terhadap norma atau kaidah BI yang memicu penggunaan BI yang sekedar berorientasi pada terjalinnya hubungan komunikasi semata;

2) kurangnya kesadaran akan adanya norma/kaidah BI yang memicu anggapan tidak perlunya penggunaan BI secara cermat, tertib, dan mengikuti kaidah yang berlaku;

3) beranggapan bahwa BI terlalu rumit atau susah sehingga memicu keengganan mempelajari bahasa Indonesia secara serius dan memicu untuk bertutur semaunya sendiri. Hal ini mengakibatkan BI lebih didominasi oleh ragam sosial, ragam gaul yang lebih berorientasi melayani selera pasar; 
4) beranggapan bahwa BI tidak lebih bergengsi dibandingkan bahasa lain (bahasa asing) sehingga menafikan keberadaan BI.

Seperti telah dipaparkan di atas bahwa konservasi dan revitalisasi bahasa termasuk pada program unggulan dan prioritas pelindungan bahasa dan satra yang sudah direncanakan dan sedang dijalankan oleh Badan Pengembangan dan Pembinaan Bahasa (Badan Bahasa), Kementrian pendidikan dan Kebudayaan. Badan Bahasa ini menyusun kinerja program yang berkaitan dengan internasionalisasi bahasa Indonesia yang meliputi:

1) Pengembangan bahasa

1. penambahan Lema KBBI

2. penambahan glosarium

3. penyusunan kamus bidang ilmu

2) Pelindungan bahasa dan sastra melalui:

a) peta vitalitas

b) revitalisasi bahasa berbasis komunitas

c) konservasi

d)fasilitasi pengembangan dan pelindungan

\section{INTERNASIONALISASI BAHASA INDONESIA}

Bahasa Indonesia sangat mungkin untuk dapat dijadikan sebagai bahasa internasional karena bahasa Indonesia sangat mudah dipelajari dan dikuasai baik oleh penutur asli maupun penutur asing. Seperti yang ditulis Subangun (2014), beberapa potensi yang dimiliki bahasa Indonesia untuk menjadi bahasa internasional antara lain didukung oleh fakta-fakta sebagai berikut.

1. Bahasa Indonesia Memiliki Kesederhanaan Struktur

Indikator kesederhanaan struktur pada bahasa Indonesia adalah: (1) tidak mengenal perubahan bentuk kata untuk menyatakan jenis kelamin; (2) menentukan kata tertentu untuk menunjukkan jamak; (3) tidak mengenal perubahan bentuk kata untuk menyatakan waktu; (4) susunan kelompok kata menggunakan hukum D-M (Diterangkan - Menerangkan); (5) mengenal lafal baku; (6) tidak mengenal bentuk kasar-halus; (7) tidak mengenal bentuk panjang pendek yang memengaruhi makna kata (Muslich (2010) dalam Subangun (2014)). Dengan struktur yang sederhana ini akan memudahkan bagi siapa pun untuk memelajari BI termasuk warga asing.

\section{Jumlah Penutur}

Jumlah penutur bahasa Melayu-Indonesia pada tahun 2011 meliputi Indonesia $( \pm 327$ juta jiwa), Malaysia ( $\pm 28,8$ juta jiwa), Brunei Darussalam ( \pm 0,3 juta jiwa), Singapura ( $\pm 5,2$ juta jiwa), Timor Leste (1,1 juta jiwa), dan Thailand ( \pm 65 juta jiwa. Jadi jumlah penutur bahasa Indonesia (Melayu) diperkirakan sejumlah 427,4 juta jiwa atau sekitar $1 / 15$ jumlah penduduk dunia yang 
berjumlah \pm 6,5 milyar jiwa. Bahkan Mendikbud menyebutkan saat ini bahasa Indonesia memiliki jumlah penutur terbesar keempat di dunia karena jumlah penduduk Indonesia sebanyak 240 juta jiwa. Dengan jumlah tersebut, peluang bahasa Indonesia menjadi bahasa internasional sangat besar.

3. Luas Penyebaran

Mendikbud menyampaikan bahwa bahasa Indonesia dipelajari di 45 negara. Sementara Kemenlu Indonesia hingga tahun 2011 mencatat 4.463.950 WNI tersebar di luar negeri, atau terbesar kelima di dunia. Selain itu, tidak kurang dari 74 negara dengan 219 lembaga di seluruh dunia menyelenggarakan program pengajaran bahasa Indonesia untuk penutur asing (BIPA).

4. Minat Warga Asing Terhadap Bahasa Indonesia

Menurut Dendy Sugono (Peneliti di Badan Bahasa, Kemendikbud) saat ini banyak orang asing yang memiliki minat yang besar untuk belajar bahasa Indonesia (Kompas, 14/11/2011). Hal ini menjadi indikasi diterimanya bahasa Indonesia dalam pergaulan internasional. Jumlah warga asing yang berminat memelajari bahasa Indonesia di pusat pembelajaran bahasa Indonesia di negara mereka, sangat tinggi. Hal ini disebabkan karena mereka merasa tertarik dengan keberagaman budaya, flora, dan fauna di Indonesia. Perkembangan pemakaian bahasa Indonesia di berbagai negara, antara lain: di Australia (menjadi bahasa terpopuler keempat dan diajarkan di 500 sekolah dasar), Mesir (membangun Pusat Studi Bahasa Indonesia), Italia (meluncurkan situs resmi berbahasa Indonesia), Jepang( sejak 1969 didirikan Nihon Indonesia Gakkai/ Perhimpunan Pengkaji Indonesia Seluruh Jepang, dibukanya Jurusan Bahasa Indonesia di beberapa PT), Vietnam ( sejak 2007, menetapkan bahasa Indonesia sebagai bahasa resmi kedua).

5. Pengguna Bahasa Indonesia di Situs Wordpress

Wordpress, salah satu jejaring sosial online (daring). Menurut pemilik Wordpress.com yaitu Matt Mullenweg "Bahasa Inggris merupakan bahasa terbesar pertama di situs wordpress, dan bahasa Indonesia menduduki urutan ketiga setelah bahasa Spanyol." Hal ini menunjukkan bahwa peminat bahasa Indonesia di dunia maya sangat tinggi.

Subangun (2014) menambahkan, meskipun peluang bahasa Indonesia menjadi bahasa internasional terbuka lebar, beberapa tantangan yang dihadapi juga sangat kompleks, yaitu sebagai berikut.

1. Rendahnya kemampuan bangsa Indonesia

Rendahnya kualitas sumber daya manusia menyebabkan sulitnya mengembangkan bahasa Indonesia ke ranah internasional. Hingga saat ini masih banyak warga Indonesia yang belum mampu berbahasa Indonesia secara baik dan benar, diantaranya dibuktikan pula melalui hasil ujian nasional mata pelajaran Bahasa Indonesia yang rendah. 


\section{Rendahnya Sikap Bangga Berbahasa Indonesia}

Akhir-akhir ini masyarakat Indonesia, terutama generasi muda, mulai kehilangan sikap bangga terhadap bahasa Indonesia sebagai bahasa nasional. Mereka merasa lebih terpelajar, modern, dan prestisius jika menyelipkan setumpuk kosakata bahasa asing dalam berbahasanya. Sikap ini diperparah oleh sikap para elite bangsa dan figur publik yang seringkali bersikap latah menggunakan kosakata asing dalam setiap tuturannya. Sikap demikian telah melemahkan harga diri bangsa Indonesia di mata dunia. Bangsa lain merasa tertarik dan menghargai keberadaan bahasa Indonesia, namun pemiliknya tidak memiliki kepedulian terhadap bahasanya.

3. Rendahnya Daya Tawar Politik dan Ekonomi

Salah satu pertimbangan suatu bahasa bisa menjadi bahasa internasional adalah peran pemilik bahasa terhadap berbagai aspek, seperti ekonomi, sosial, dan budaya. Makin kuat peran bangsa dalam berbagai aspek tersebut, maka makin kuat daya tawar terhadap bangsa di dunia. Saat ini bangsa Indonesia belum intens dalam berbagai aspek tersebut sehingga daya tawar bangsa Indonesia masih rendah.

\section{SIMPULAN}

Berdasarkan uraian di atas, maka dapat disimpulkan sebagai berikut.

1. Bahasa Indonesia sebagai bahasa nasional dan bahasa negara ditingkatkan fungsinya menjadi bahasa internasional seperti yang tercantum pada UndangUndang Nomor 24 Tahun 2009 tentang Bendera, Bahasa, dan Lambang Negara, serta Lagu Kebangsaan, pasal 44 menyebutkan bahwa (1) Pemerintah meningkatkan fungsi Bahasa Indonesia menjadi bahasa internasional secara bertahap, sistematis, dan berkelanjutan; (2) Peningkatan fungsi bahasa Indonesia menjadi bahasa Internasional sebagaimana dimaksud pada ayat (1) dikoordinasi oleh lembaga kebahasaan; (3) Ketentuan lebih lanjut mengenai peningkatan fungsi bahasa Indonesia menjadi bahasa internasional sebagaimana dimaksud pada ayat (1) diatur dalam peraturan pemerintah.

2. Pusat Pengembangan dan Pelindungan (Pusbanglin), Badan Pengembangan dan Pembinaan Bahasa (Badan Bahasa), Kementerian Pendidikan dan Kebudayaan memiliki strategi untuk mewujudkan internasionalisasi bahasa Indonesia. Strategi yang akan dilakukan menurut Dr. Sugiyono (Kepala Pusat Pengembangan dan Pelindungan) adalah: "Pertama, meningkatkan jumlah kosakata. Kedua, mengembangkan Uji Kemahiran Berbahasa Indonesia (UKBI). Ketiga, menyusun kamus ASEAN dan akan diberi nama kamus Masyarakat Ekonomi ASEAN (MEA), serta kerja sama dengan kedutaan dan perguruan tinggi." Selain ketiga strategi yang mendukung internasionalisasi 
bahasa Indonesia di atas, Pusbanglin juga memiliki program pelindungan, yaitu konservasi dan revitalisasi bahasa dan sastra Indonesia dan daerah.

3. Konservasi bahasa Indonesia adalah melakukan pemeliharaan dan perlindungan secara teratur terhadap bahasa Indonesia untuk mencegah terjadinya kerusakan atau kemusnahan pada bahasa Indonesia. Revitalisasi bahasa adalah upaya untuk mengembalikan bahasa yang terancam punah pada tingkat penggunaan yang lebih baik dalam masyarakat setelah mengalami penurunan penggunaan.

4. Beberapa potensi yang dimiliki bahasa Indonesia untuk menjadi bahasa internasional antara lain: bahasa Indonesia memiliki kesederhanaan struktur; bahasa Indonesia memiliki jumlah penutur terbesar keempat di dunia; bahasa Indonesia dipelajari di 45 negara; banyak orang asing yang memiliki minat yang besar untuk belajar bahasa Indonesia; bahasa Inggris merupakan bahasa terbesar pertama di situs wordpress, dan bahasa Indonesia menduduki urutan ketiga setelah bahasa Spanyol.

5. Meskipun peluang bahasa Indonesia menjadi bahasa internasional terbuka lebar, beberapa tantangan yang dihadapi juga sangat kompleks, yaitu: hingga saat ini masih banyak warga Indonesia yang belum mampu berbahasa Indonesia secara baik dan benar; rendahnya sikap bangga berbahasa Indonesia; rendahnya daya tawar politik dan ekonomi

\section{DAFTAR PUSTAKA}

Asrini, Hari Windu. 2014. Memperkokoh Kedudukan Bahasa Indonesia: Meneguhkan Sikap Positif Terhadap Bahasa Indonesia dalam Prosiding Seminar Internasional. Universitas Muhammadiyah Malang, 4-5 November 2014.

Badan Pembinaan dan Pengembangan Bahasa. 2016. Badan Bahasa: Upaya Internasionalisasi Bahasa Indonesia dan Pelindungan Bahasa dan Sastra Daerah. http://badanbahasa.kemendikbud.go.id

Budiwiyanto. Adi. 2016. Pendokumentasian Bahasa dalam Upaya Revitalisasi Bahasa Daerah yang Terancam Punah di Indonesia. http://badanbahasa.kemendikbud.go.id. (artikel)

Kementerian Pendidikan dan Kebudayaan. 2016. Program Unggulan dan Prioritas Badan Pengembangan dan Pembinaan Bahasa. Program_Badan_Bahasa.pdf.

Muslich, Masnur. dan I gusti Ngurah Oka. 2010. Perencanaan Bahasa pada Era Globalisasi. Jakarta: PT. Bumi Aksara

Subangun. 2014. Peran Bahasa Indonesia sebagai Bahasa Ilmu Pengetahuan dan Bahasa Internasional dalam Membangun Peradaban Manusia dalam 
Prosiding Seminar Internasional. Universitas Muhammadiyah Malang, 4-5 November 2014.

Sulistyaningsih, Tri. 2014. Implementasi Kebijakan Politik Bahasa Indonesia di Era Globalisasi dalam Prosiding Seminar Internasional. Universitas Muhammadiyah Malang, 4-5 November 2014.

Undang-Undang Republik Indonesia Nomor 24 tahun 2009 tentang Bendera, Bahasa, dan Lambang Negara, serta Lagu Kebangsaan. 